\title{
GRATITUDE THERAPY CAN INCREASE HAPPINESS FOR WOMEN VICTIMS OF VIOLENCE
}

\author{
Adisti Natalia, Hally Weliangan \\ nataliaadisti36@gmail.com \\ Faculty of Clinical Psychology, Gunadarma University
}

\begin{abstract}
This study aims to test the effectiveness of gratitude therapy to increase happiness in women victims of violence who live in Panti Sosial Perlindungan Bhakti Kasih. This type of research uses one group pretestposttest experiment. The hypothesis of this study is that gratitude therapy is effective for increasing happiness scores in women victims of violence. The results of this study indicate that gratitude therapy is effective in increasing the happiness score of the participants, with a significance level of $0.018(\rho<0.05)$, which means that there are differences in happiness scores before and after being given the intervention in the form of gratitude therapy.
\end{abstract}

\section{Keyword: Gratitude Therapy, Women Victims of Violence, Happiness}

\section{PREFACE}

Cases of violence against women occur in most countries in the world, every year many women experience violence both physically, verbally and sexually, as quoted from Serabinews which states that data from the United Nations records that $35 \%$ of women in the world have experienced violence by physically, verbally and sexually (Wihoho, 2017). According to WHO (2017) as much as 38\% of homicides against women are committed by their closest people, especially their partners. According to the New York-based statistical portal, there were 98,856 rape cases in the United States in 2017, with a national figure of 30.7 cases per 100,000 people, while according to the European Union's statistics office the police recorded 215,000 sexual crimes against women. Of these, 80,000 cases were rape (Dongantekin, 2019). In Indonesia, according to data from Komnas Perlindungan Perempuan (2019), it was recorded that in 2018 there were 406,178 cases of violence against women, an increase of around $14 \%$ compared to 2017 which was only 348,446 cases, of all cases it was reported that $71 \%$ of violence was committed by people closest to them, for example husbands against wives, women who have been abused by their own boyfriends, and others.

According to Komnas Perempuan (2018), violence against women will have a physical impact such as injuries, permanent physical disabilities, sexual diseases, menstrual cycle disorders and appetite disorders, as well as psychological impacts in the form of feelings of inadequacy or helplessness, depression, paranoia, fear, sleeplessness and poor psychological and emotional well-being. The same thing was said by Astutik and Laksono (2015) in a journal entitled Kekerasan Gender dalam Berpacaran Dikalangan Mahasiswa, stating that most victims of violence experience psychological disorders in the form of anxiety $(37.20 \%)$, easily offended $(20.93 \%)$, difficult sleep $(18.60 \%)$, nervousness $(9.30 \%)$, low self-esteem $(4.65 \%)$, and fear $(4.65 \%)$. These negative feelings in the end make women victims of violence feel that their lives are unhappy.

According to Argyle (2002) one aspect of happiness is the existence of good memories, where individuals do not have a bad and traumatic past. Women victims of violence have a bad past, where these women experience violence by their closest people, this is what makes women victims of violence unhappy. As well as the results of research from Vazques, Panadero, and Rivas (2017) which examined women victims of violence in Nicaragua, stated that as many as $60 \%$ of these women experienced unhappiness.

Meanwhile, according to Aristoles (in Adler, 2003) states that the main goal of humans is happiness, where everyone in the world will try to achieve happiness itself. The same thing was said by Seligman (2005), that every human being has the potential to live happily and lead a good life. Likewise women who are victims of violence, these women also want to feel happiness.

Happiness itself is defined as positive feelings and positive activities without any compulsion at all from one's condition and ability to feel emotions in the past, future, and present (Seligman, 2005). 
Individuals who do not feel happy can cause feelings of sadness, fear, anxiety and other negative feelings. This is supported by the results of research from Moreno, Heise, Jansen, Ellsberg, and Watts (2005) which state that women who are victims of violence and do not feel happy tend to have negative feelings that can increase thoughts of suicide.

Therefore, appropriate interventions are needed to increase happiness in women victims of violence. One of the interventions that can be used is by doing a gratitude therapy. Gratitude itself is a recognition of the good in an individual's life and acknowledges the source of that goodness (Emmons, 2007). Meanwhile, according to Lazarus and Lazarus (1994), it defines that gratitude is one of the empathic emotions that is rooted in the ability to empathize with other people.

Gratitude therapy is practiced by saying thank you and expressing the gratitude every day, being grateful for everything in life, and can reduce negative emotions and increase positive emotions that exist in individuals. With gratitude therapy, according to McCullough (2008), it can bring out pleasant emotions because gratitude will bring benefits to yourself or others.

Meanwhile, according to Seligman (2005), one of the factors that can increase happiness is gratitude, where the feeling of gratitude for the good things in life will increase positive memories. Where these positive memories can make individuals have a high level of happiness. The results of research from Eriyanda and Kharaini (2018) show that there is a significant relationship between thanksgiving and happiness in divorced women in Aceh. The same thing was expressed by Ferer (2017) who said that there was a significant relationship between thanksgiving and happiness in students.

Based on the description above, this study aims to increase happiness in women victims of violence by using gratitude therapy.

\section{RESEARCH METHODS}

\section{a. Research Participants}

Participants in this study were women who were victims of violence by physically, psychologically and sexually. Participants age around the age of 20 years - 40 years. There were 7 participants who took part in this intervention, where all participants had criteria such as experiencing physical, psychological and sexual violence, had low scores on happiness, and gratitude, could read or write, and did not experience psychotic disorders.

\section{b. Research Design}

The design in this study was carried out in the form of an experiment with one group, namely the experimental group, in which the group was given intervention in the form of grateful therapy intervention. This study used an experimental one group pretest-posttest design.

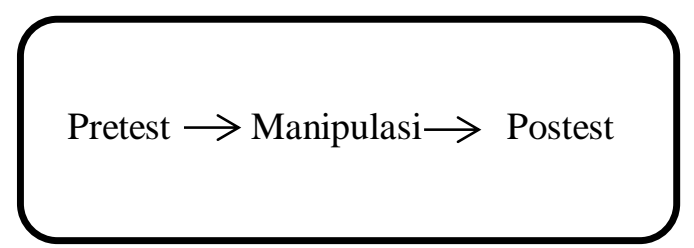

\section{c. Data Collection Method}

Collecting data in this study is conducted by using the Perma measuring instrument twice which aims to measure happiness and the Gratitude Questionnaire-Six Item Form (GQ-6) measurement tool, which aims to measure the participants' level of gratitude. The first measurement was done before the thanksgiving therapy intervention (pretest) and the last measurement was done after the researcher gave the intervention participant in the form of gratitude therapy (posttest).

\section{d. Intervention Procedure}

The research instruments used in this study were: Perma as a measure of happiness, The Gratitude Questionnaire-Six Item Form (GQ-6) as a measure of gratitude, a letter of informed consent for participants, modules and design of gratitude therapy activities.

The preparation of research interventions includes: Initial assessment to analyze needs, determine participants, determine appropriate therapy for the participants, compile a gratitude therapy guide module, fill out an informed consent form, implement the intervention carried out by the researcher and assisted by two colleagues from the researcher Participants were given gratitude therapy in groups. This research was conducted for 4 meetings, 2 times a week, with each meeting lasting approximately 120 minutes- 150 minutes. The intervention session was made by referring to the intervention stages of Snyder and Lopes (2002), namely identifying wrong thoughts, formulating and supporting thoughts of gratitude, replacing wrong thoughts with thoughts of gratitude, and applying gratitude and inner and outer actions. 


\section{Data Analysis Method}

Data analysis was conducted by quantitatively and qualitatively. The quantitative analysis was carried out by using the Wilcoxon difference test for the differences between the pretest and posttest results with the help of SPSS for Windows 2.

\section{a. Quantitative Analysis Results}

1) Bivariate Analysis

The bivariate analysis aims to see the difference in happiness scores between before and after being given gratitude therapy.

\begin{tabular}{cc}
\hline$Z$ & Sig. (2-tailed) \\
& \\
\hline-2.366 & .018 \\
\hline
\end{tabular}

The table shows that the Wilcoxon test obtained $\mathrm{p}$ value $=0.018(\mathrm{p}<0.05)$. This shows that there is a difference in happiness scores between before and after being given gratitude therapy.

\section{2) Univariate Analysis}

This univariate analysis is used to see the frequency distribution of happiness scores before and after being given thanksgiving therapy interventions for women who experience violence both physically, psychologically and sexually.

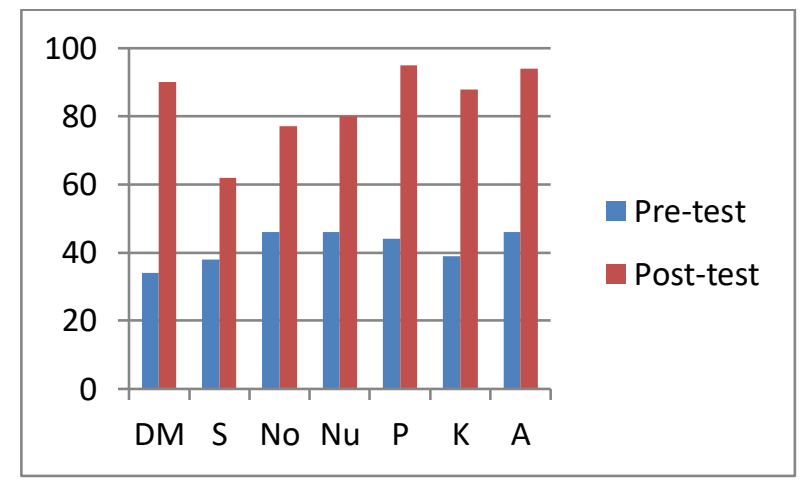

Graphic. Pre-test and Post-test Happiness

Based on the graph above, it can be concluded that all participants experienced an increase in happiness before and after the intervention was given.

\section{b. Qualitative Analysis Results}

In addition to paying attention to the responses from participants in the form of a questionnaire, the researcher also conducted interviews with all participants. On average, the participants said that they felt happy when they intervened in gratitude therapy, especially when the participants were asked to write down what aspects that make them feel grateful for each day. When writing, the participants realized that there were many things to be grateful for in their life, this was what made the participants feel happy, because prior to the intervention, they felt that there was nothing that they could be grateful for from their life.

\section{Discussion}

Based on the Wilcoxon test, it is known that there is a difference in happiness scores between before and after the intervention with a significance level of $0.018(\rho<0.05)$. This means that the hypothesis in this study is accepted, namely that gratitude therapy is effective in increasing happiness in women victims of violence. The results of this study are consistent with the results of research conducted by Emmons and Stern (2013), which states that gratitude therapy is effective for increasing happiness and other positive emotions.

Initially, the average participant admitted that there were no things in life to be grateful for that made participants happy. They feel that their life is full of unused feelings such as fear, anxiety, sadness, 
and anger. These feelings make them unhappy. After participating in gratitude therapy, all participants experienced an increase in their happiness scores.

The participants' happiness scores increased after being given an intervention in the form of gratitude therapy. This can be seen from the average score of happiness before and after gratitude therapy. Initially, the average happiness score for participants was 41.86. After being given gratitude therapy, the happiness score for the participants increased to 83.71. Participants said that after being given gratitude therapy, especially when writing simple things to be grateful for and being able to make happiness in everyday life, it made them feel happier. When writing it, the participants felt that many simple things that were found everyday can make participants happy. This is supported by the results of research from Watkins, Woodward, and Stone (2003) which state that individuals who can express gratitude can feel more happiness than individuals who cannot express gratitude.

In addition, the participants also revealed that after participating in gratitude therapy, they became more appreciative and loving themselves. They are able to discover many good aspects in life that they can be grateful for. As said by one of participant named $\mathrm{Nu}$, after she followed gratitude therapy, especially when she wrote down all aspects that make her feel grateful every day, Nu became more aware of positive things that she was not previously aware of, which made her more confident, and respected herself.

According to Myers (2002), a happy person is someone who loves himself/ herself. He/ she respects his/ her strengths and weaknesses, has self-confidence, and considers himself more moral, smarter, and healthier than other people. These factors ultimately made participants feel happier after following the gratitude therapy intervention.

In addition, according to Seligman (2005), one of the strenghts of happiness is gratitude, where a grateful individual is a person who is aware of the good things that have happened to him/ her and never ignores them, always feel grateful and always makes time to say thank you. When participating in the gratitude therapy intervention, the participants admitted that they were more aware of the good things in their life, which had not previously been realized. When realizing these good things, finally, the participants have the strength to be happier. They also admitted that by expressing gratitude to those who contributed to them, it helped them to have more positive thoughts, and they felt more loved. As Nu said, when she wrote a letter of thanks, she remembered that there are many people who still care and love her, which makes her feel happier. The same thing was said by No who said when writing letters to people who contributed to her life, it made her feel loved and happy.

In this study, the measurement of the gratitude score was also conducted in order to see whether the participants needed gratitude therapy or not. When the participants were examined before following gratitude therapy, the average score of the seven participants was 11.71, and after being given gratitude therapy, the average score of the seven participants was 27.86 . This means that gratitude therapy can increase the participants' racial gratitude.

According to the participants, when following the gratitude therapy intervention, they became more aware of the strengths that the they had since previously the participants thought that they did not have any advantages, so that nothing that they could be grateful for from their lives. This factor is what ultimately makes the participants' gratitude scores increase after being given gratitude therapy. According to McCullough (2002), one of the factors an individual can be grateful for is emotional well-being, where individuals tend to react emotionally and feel that they judge their life satisfaction. Individuals can be grateful when they feel that their lives are fulfilling. This is what the WBS participants felt. Where the WBS can find positive things in themselves and make participants be grateful for them.

This statement is also supported by the results of research from Ferrer (2017), where there is a relationship between gratitude and life satisfaction. Individuals can be grateful when the individual has good life satisfaction. This is what was felt by some participants, as said by participant DM, where in the past she did not know the strengths in herself, but after following the intervention, DM became more aware of her strengths and had a new spirit of life. The same thing was said by participant $\mathrm{K}$, whom initially thought that she had no advantages, but after following the intervention, she can discover her strengths and made her more grateful for what she had in her life. Participant A also said that after knowing her own strengths, she became more excited and happy to achieve her goals.

Prior to gratitude therapy, the participants did not realize this. Participants assume that everything that happens in their life is negative, which makes them feel less confident, and do not respect themselves. After the participants followed the gratitude therapy, they felt that there were many things that could be found in themselves and their lives that could make the them feel happy.

\section{Conclusion}

The results of this study indicate that the hypothesis that has been formulated is acceptable: Gratitude therapy can increase happiness for women victims of violence who live in the Panti Sosial Perlindungan Bhakti Kasih. The results of the Wilcoxon difference test showed a significance level of $0.018(\rho<0.05)$. This shows that there are differences in happiness scores before and after being given thanksgiving therapy. 
Based on the results of interviews with the participants, it is known that after being given gratitude therapy, they become more aware of their strengths and they realize that there are many positive things that they can be grateful for, which can increase happiness score in themselves. In addition, the participants also feel happy every time they write things they are grateful for every day. The participants also feel calm every time they doing that.

\section{Suggestion}

\section{a. For Participants}

The participants are expected to continue writing things that they are grateful for everyday, and be able to see the positive things in their life, so the participants can increase their happiness level.

\section{b. For Further Researchers}

For further researchers, it is hoped that it will be able to extend the existing duration of gratitude therapy, so that later the happiness score can be further increased. In addition, further researchers are expected to be able to increase the number of thankful therapy sessions and make the thankful therapy sessions more varied.

\section{References}

Adhitia, F.B. (2018). 3 Faktor penyebab angka kekerasan pada perempuan terus meningkat. https://www.idntimes.com/news/indonesia/fitang-adhitia/3-faktor-penyebab-angka-kekerasan-padaperempuan-terus-meningkat/full

Adler, J. (2003). Aristotle's ethics: the theory of happiness-1: Illinois University Press

Argyle, M. (2001). The psychology of happiness. New York: Routledge Taylor \& Francis Group.

Astutik, J., \& Laksono, S.P. (2015). Kekerasan gender dalam berpacaran di kalangan mahasiswa (studi kasus di Malang). Jurnal Perempuan dan Anak, 1(1) 1-22.

Dogantekin, V. (2019). Kekerasan seksual di AS dan Eropa terus meningkat. Diakses pada tanggal 14 Mei 2019 dari https://www.aa.com.tr/id/dunia/kekerasan-seksual-di-as-dan-eropa-terus-meningkat/1401287.

Emmons, R.A. (2007). Thanks! : How the new science of gratitude can make you happier. New York: Houghton Mifflin Company.

Emmons, R., \& Stern, R. (2013). Gratitude as a psychotherapeutic intervention. Journal of Clinical Psychology. 69(8).

Eriyanda, D., \& Khairani, M. (2018). Kebersyukuran dan kebahagiaan pada wanita yang bercerai di Aceh. Psikodimensia. 16(2).

Ferrer, C.S. (2017). The relationship between gratitude and life satisfaction in sample of Spanish university students: The moderation role of gender. Anales de Psicologia. 33(1).

Komnas Perlindungan Perempuan. (2019). Catatan kekerasan terhadap perempuan tahun 2018. https://www.komnasperempuan.go.id/file/Catatan\%20Tahunan\%20Kekerasan\%20Terhadap\%20Perem puan\%202019.pdf

McCullough, M.E., \& Emmons, R.A. (2004). The psychology of gratitude. New York: Oxford University Press, Inc.

Moreno, G.C., Jansen, H., Ellsberg, M., Heise, L., \& Watts, C.H. (2005). WHO Multi-Country Study on womens health and domestic violence against women study team. Lancet, 3(6).

Myers, D. (2002). The pursuit of happiness: Who is happy and why? Harper: Paperbacks.

Seligman, M.E.P. (2005). Authentic happines: Menciptakan kebahagiaan dengan psikologi positif. Bandung: PT. Mizan Pustaka.

Synder, C.R., \& Lopez, S.J. (2002). Handbook of positive psychology. New York: Oxford University Press.

Vaquez, J.J., Rivas, E., \& Panadero. (2017). Retraction of complaints among female victims of intimate partner violence living in poverty in Nicaragua. Sage Journals, 62(10), 3151-3167.

Watkins, P.C., Woodward, K., Stone, T., \& Kolts, R.L. (2003). Gratitude and happiness Development of a measure of gratitude, and relationships with subjective well-being. Society for Personality Research. $31(5)$.

Wihoho, L.H. (2017). Data PBB, 35 persen perempuan di dunia pernah mengalami kekerasan fisik dan seksual. Diakses pada tanggal 14 Mei 2019 dari https://aceh.tribunnews.com/2017/11/29/data-pbb-35persen-perempuan-di-dunia-pernah-mengalami-kekerasan-fisik-dan-seksual

WHO. (2017). Violence against women. https://www.who.int/news-room/fact-sheets/detail/violence-againstwomen 